\title{
Rancang Bangun Sistem Keamanan Sepeda Motor Dengan GPS Tracker Berbasis Mikrokontroler dan Aplikasi Andrloid
}

\author{
I Gusti Agung Made Yoga Mahaputra ${ }^{1}$, I Gusti Agung Putu Raka Agung ${ }^{2}$, Lie Jasa ${ }^{3}$ \\ Submission: 20-08-2019, Accepted: 30-08-2019
}

\begin{abstract}
The motorcycle is one of the most widely used types of transportation in Indonesia. The disadvantage of the motor currently lies in its safety. motorcycle safety system designed function to monitor and control the motorcycle through the Android application. Security system testing with three main tests. Testing of motorcycle safety equipment is done by testing each module. Android application testing is done by running the monitoring and control functions. Testing the communication with the application is done by sending commands from the smartphone to the device. The system can run all commands. Motorcycle safety devices can communicate with Android applications and can detect coordinates. The Simcard operator affects the network installation time on the SIM900A module where Telkomsel has speed of 6 seconds, M3 has 31 seconds and XL has 310 seconds. There is a difference between the reading value between the actual distance of the motorcycle and the distance of the motorcycle to the instrument reaching 4 meters.
\end{abstract}

Keyword- GPS NEOM8N, Motorcycle, Security System, SIM900A.

Intisari-Sepeda motor adalah salah satu jenis transportasi yang paling banyak digunakan di indonesia. Kekurangan sepeda motor saat ini terletak pada keamanannya. Sistem keamanan sepeda motor yang dirancang berfungsi untuk memonitoring dan mengontrol sepeda motor melalui aplikasi Android. Pengujian sistem keamanan dilakukan dengan tiga tes utama. Pengujian alat pengaman sepeda motor dilakukan dengan menguji setiap modul alat. Pengujian aplikasi Android dilakukan dengan menjalankan fungsi monitoring dan kontrol. Pengujian komunikasi dilakukan dengan mengirim perintah dari smartphone ke alat. Berdasarkan hasil pengujian yang telah dilakukan, sistem dapat menjalankan semua perintah. Alat keselamatan sepeda motor dapat berkomunikasi dengan aplikasi android dan dapat mendeteksi koordinat. Operator Simcard memengaruhi waktu pairing pada modul GSM di mana Telkomsel memiliki kecepatan pemasangan 6 detik, M3 memiliki kecepatan 31 detik dan XL memiliki kecepatan 310 detik. Terdapat selisih nilai pembacaan antara Jarak perpindahan sepeda motor sebenarnya dengan jarak perpindahaan sepeda motor pada alat mencapai 4 meter sehingga toleransi keakuratan dari alat adalah kurang lebih 4 meter.

Kata Kunci- GPS NEOM8N, Sepeda Motor, SIM900A, Sistem

${ }^{1}$ Mahasiswa,Program Studi Teknik Elektro Fakultas Teknik Universitas Udayana, Jalan Veteran no 17, Denpasar 80231. Indonesia (telp: 0361-4745347;email:yogamahaputra27@gmail. com)

${ }^{2,3}$ Dosen,Program Studi Teknik Elektro Fakultas Teknik Universitas Udayana, Jln. Jalan Kampus Bukit Jimbaran 80361 INDONESIA (telp: 0361-703315; fax: 0361-4321; e-mail:

\section{Keamanan.}

\section{PENDAHULUAN}

Indonesia adalah negara dengan jumlah penduduk tertinggi no 4 di dunia di mana menurut proyeksi penduduk yang dimuat oleh Badan Pusat Statistik Indonesia melalui sensus peduduk tahun 2010, di mana peningkatan jumlah penduduk dari 2018 sampai 2034 meningkat sampai 16\% atau mencapai jumlah 303 juta jiwa pada tahun 2034 [1]. Dari jumlah penduduk Indonesia yang besar tersebut dibutuhkan perkembangan ekonomi yang baik dalam meningkatkan kesejahteraan masyarakat. Salah satu sarana dalam menunjang perkembangan ekonomi dan sosial adalah transportasi.

Sepeda motor adalah salah satu transportasi yang paling banyak digunakan oleh masyarakat indonesia karena harganya yang relatif murah, mudah digunakan, dan mempunyai fleksibilitas tinggi. Di balik kelebihan yang terdapat pada sepeda motor, terdapat kekurangan salah satunya rawan pencurian dikarenakan keamanan motor saat ini belum mampu dengan maksimal mencegah terjadinya pencurian sepeda motor. Berdasarkan data dari Polda Bali di mana kasus pencurian motor terjadi hampir setiap hari di Bali. Kasus pencurian motor terus meningkat setiap tahunnya dimana sepanjang tahun 2016 telah terjadi 451 kasus dibandingkan dengan tahun sebelumnya yaitu 401 kasus di mana kasus paling banyak pada saat motor dalam keadaan terparkir dan diluar pengawasan pengguna [2].

Oleh karena itu dikembangkan alat keamanan sepeda motor yang dapat mendeteksi pergerakan sepeda motor saat sepeda motor dalam keadaan terparkir dan terhubung ke aplikasi Android dengan tampilan yang user frendly. Alat yang akan dikembangkan menggunakan Arduino Nano Atmega328 sebagai kontroler utamanya, GSM 900A sebagai media transmisi data melalui SMS, GPS Neo M8N sebagai navigasi pelacak koordinat dari alat, IC LM7805 sebagai regulator tegangan $5 \mathrm{~V}$. Penelitian ini diharapkan dapat membantu meningkatkan keamanan sepeda motor dan mengurangi angka kehilangan sepeda motor yang terus bertambah setiap tahunnya.

\section{KAJIAN PUSTAKA}

\section{A. Sepeda Motor}

Sepeda motor adalah kendaraan beroda dua dimana sepeda motor merupakan pengembangan dari sepeda konvensional yang sudah ditemukan sebelumnya [3]. Sepeda motor digunakan sebagai alat transportasi yang memiliki kelebihan tingkat fleksibelitas dan kemudahan pemakaian dengan biaya yang murah dibandingkan menggunakan mobil. Gambar 1

I Gustı Agung Made Yoga Mahaputra: Kancang Bangun Sistem Keamanan... P p-ISSN:1693 - 2951; e-ISSN: 2503-2372 
menunjukkan sepeda motor jenis matik dengan merek beat yang akan digunakan pada penelitian.

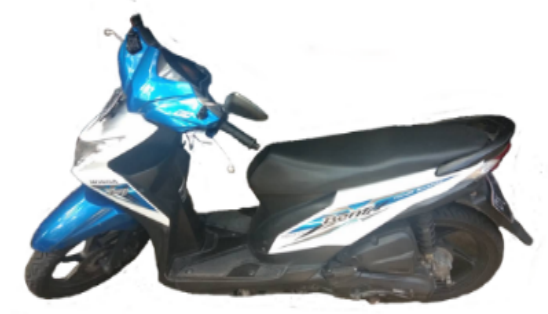

Gambar 1: Gambaran Sepeda Motor Beat FI 2014

\section{B. Arduino Nano Atmega 328}

Arduino adalah salah satu mikrokontroler yang sering digunakan dikarenakan sifatnya yang open source dimana semua orang dapat mempelajari serta mengembangkan prototype dari arduino dan membuat versi dengan brand mereka sendiri [4].Bahasa yang digunakan pada pemrograman arduino adalah bahasa $\mathrm{C}$ dimana bahasa ini sudah dipermudah menggunakan fungsi fungsi sederhana sehingga pemula dapat mempelajari arduino dengan mudah. Gambar 2 menunjukkan fungsi setiap pin yang terdapat pada arduino nano. Program yang dibuat dengan arduino IDE disebut dengan sketches [5].

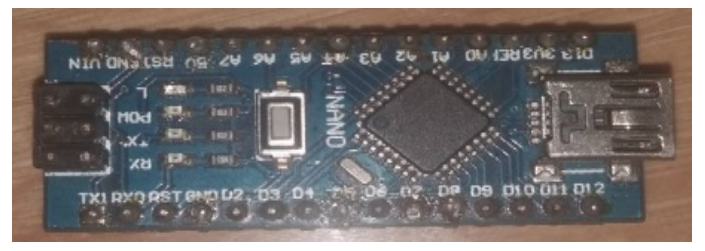

Gambar 2: Konfigurasi Arduino Nano

\section{GPS Neo M8N}

Global Position System adalah kepanjangan dari GPS merupakan sistem navigasi berbasis satelit yang dikembangkan oleh Departemen Pertahanan Amerika untuk kebutuhan militer [6]. Semakin majunya teknologi, penggunaan GPS sudah dikembangkan dan digunakan pada pengaplikasian yang lebih luas. GPS saat ini sudah di aplikasikan ke berbagai macam jenis alat seperti keperluan navigasi pada mobil, Pemetaan suatu wilayah, dan sistem pelacak benda. Salah satu modul GPS yang sering dipakai dalam pembuatan alat berbasis mikrokontroler adalah modul GPS Neo N8M dimana modul GPS ini adalah salah satu seri terbaru yang ada di pasaran saat ini. Gambar 2.6 merupakan modul GPS NEO-M8N yang digunakan pada penelitian ini.

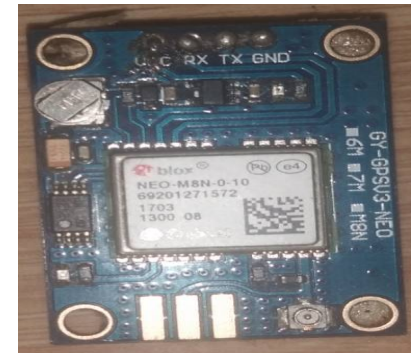

Gambar 3: Modul GPS NEO M8N

\section{SIM900A}

Modul GSM SIM900A adalah modul yang berfungsi menggantikan telepon selular dalam mengirim dan menerima data SMS[7]. GSM/GPRS yang dapat digunakan untuk mengirim SMS, melakukan panggilan suara, transfer data melalui GPRS dan fungsi DTMF [8]. Modul GSM SIM900A dapat bekerja pada frekuensi 900/1800MHZ dengan daya yang rendah. Dengan desain yang kecil, Modul SIM900A dapat digunakan pada alat alat yang memiliki ukuran kecil sehingga dapat menghemat ruang. SIM900A dapat bekerja dengan rentang tegangan $3,4 \mathrm{~V}$ hingga $5 \mathrm{~V}$. dikarenakan komunikasi SMS memiliki kelebihan jaringan yang terbuka dan akses yang mudah, komunikasi SMS memiliki kekurangan dalam penanggulangan phishing dan spam[9].

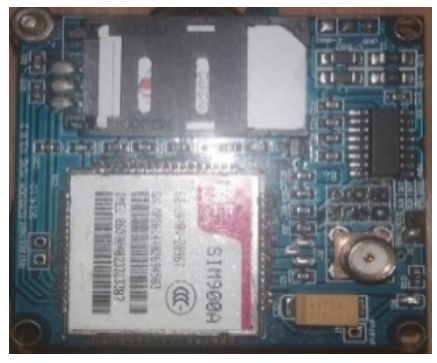

\section{E. Thunkable}

Gambar 4: Modul SIM900A

Thunkable adalah salah satu aplikasi atau tools IDE open sourse dimana thunkable tersedia untuk pembuatan aplikasi jenis mobile yaitu android dan IOS dalam keperluan programmer atau mobile developer [10]. Thunkable memberikan kemudahan dalam pembuatan aplikasi android maupun IOS karena dalam perancangan interface digunakan sistem drap and drop elemen pallete dan untuk sistem pemrogrammannya digunakan sistem pembuatan kode yang disebut block yang juga menggunakan sistem drap and drop. Googlemap API digunakan untuk menerima hasil pengukuran koordinat [11].

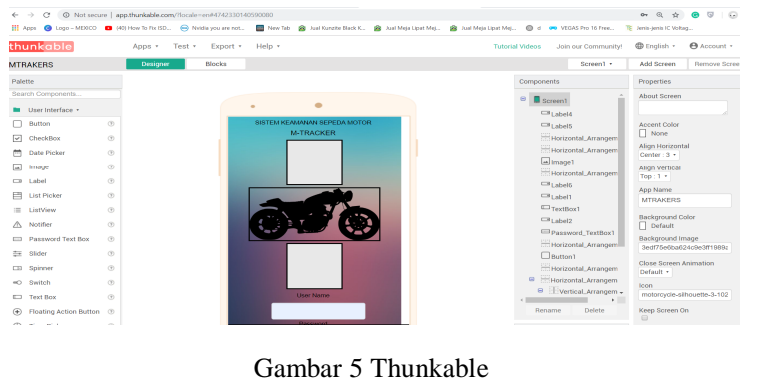




\section{Metodologi Penelitian}

A. Diagram Blok Hardware Sistem Keamanan Sepeda Motor yang Dirancang

Pada diagram blok hardware dibagi menjadi 3 bagian yaitu input, pemrosesan, dan output. Gambar 3.1 menunjukkan diagram blok hardware dari Sistem Keamanan Sepeda Motor dengan GPS Tracer berbasis Mikrokontroler dan Aplikasi Android.

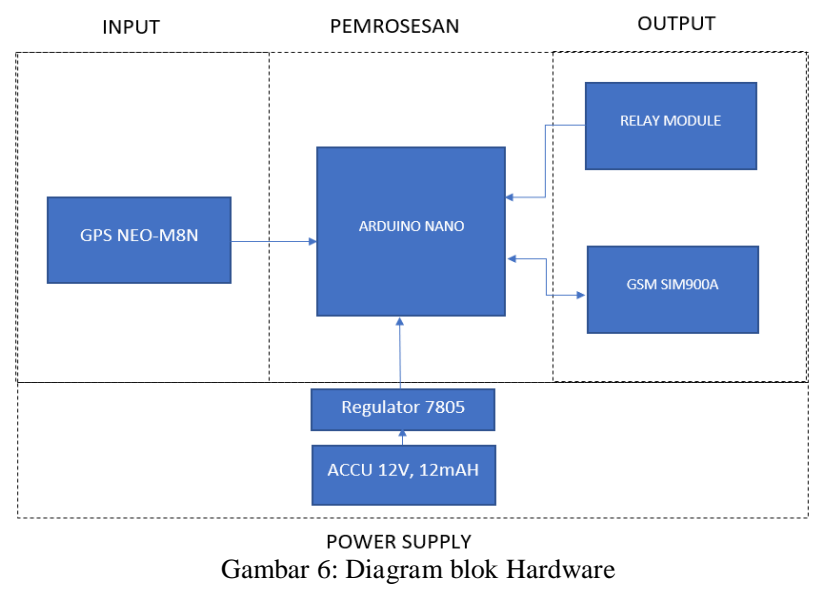

B. Bagian bagian Software Sistem Keamanan Sepeda Motor yang Dirancang

Bagian software sistem keamanan sepeda motor terdapat dibagi menjadi 2 yaitu software pada alat keamanan sepeda motor dan software aplikasi Android. Gambar 3.2 merupakan bagian software dari Sistem Keamanan Sepeda Motor.

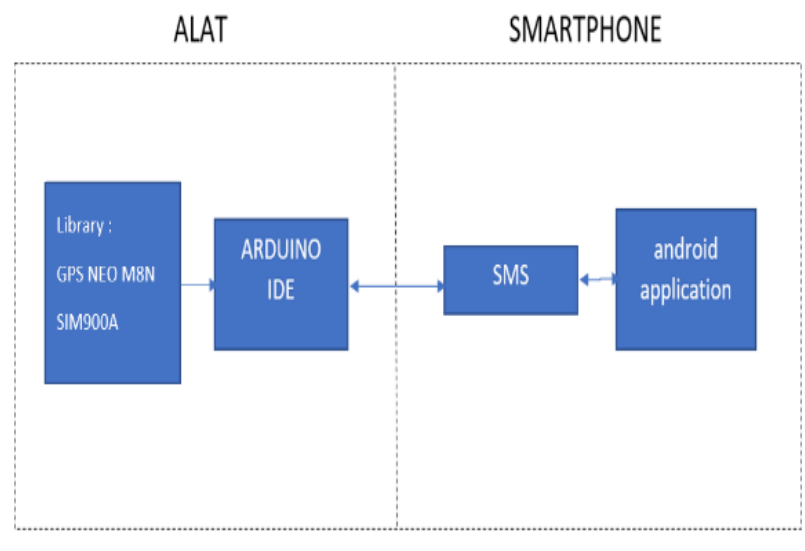

Gambar 7: bagian bagian Software Sistem Keamanan Sepeda Motor

C. Perhitungan Perpindahan Jarak Sebenarnya dengan Perpindahan Jarak pada Alat

Data akan dibandingkan untuk mendapatkan jarak perpindahan dari titik awal ke titik akhir dengan menggunakan teori Eucldian Distance yaitu formula untuk mengukur jarak dari 2 titik dengan menggunakan hitungan matematis [12]. Perhitungan jarak dengan Euclidean Distance ditunjukan pada rumus pada 3.1 .

Jarak $=\left(\sqrt{(\text { lat } 1, \text { lat } 2)^{2}+(\text { long } 1, \text { long } 2)^{2}}\right) \times 111.319$

Keterangan :

- lat1 = koordinat Lattitude Pembanding

I Gusti Agung Made Yoga Mahaputra: Rancang Bangun Sistem Keamanan...
$=$ Koordinat Lattitude Realtime

- lat2

= Koordinat Longtitude Pembanding

- long2 = Koordinat Longtitude Realtime

Dapat dilihat bahwa data dikalikan dengan nilai 111.319 $\mathrm{km}$ karena nilai tersebut adalah jarak dari 1 derajat bumi [13].

D. Flowchart Sistem Keamanan Sepeda Motor

Pembuatan Diagram alir (flowchart) menggambarkan proses kerja Rancang Bangun Sistem Keamanan Sepeda Motor dengan GPS Tracker berbasis Mikrokontroler dan Aplikasi Android dibagi menjadi 2 bagian utama yaitu:

1). GPS Tracker pada Sepeda Motor

Diagram alir (flowchart) dari Sistem Keamanan Sepeda Motor ditunjukkan pada Gambar 3.3.

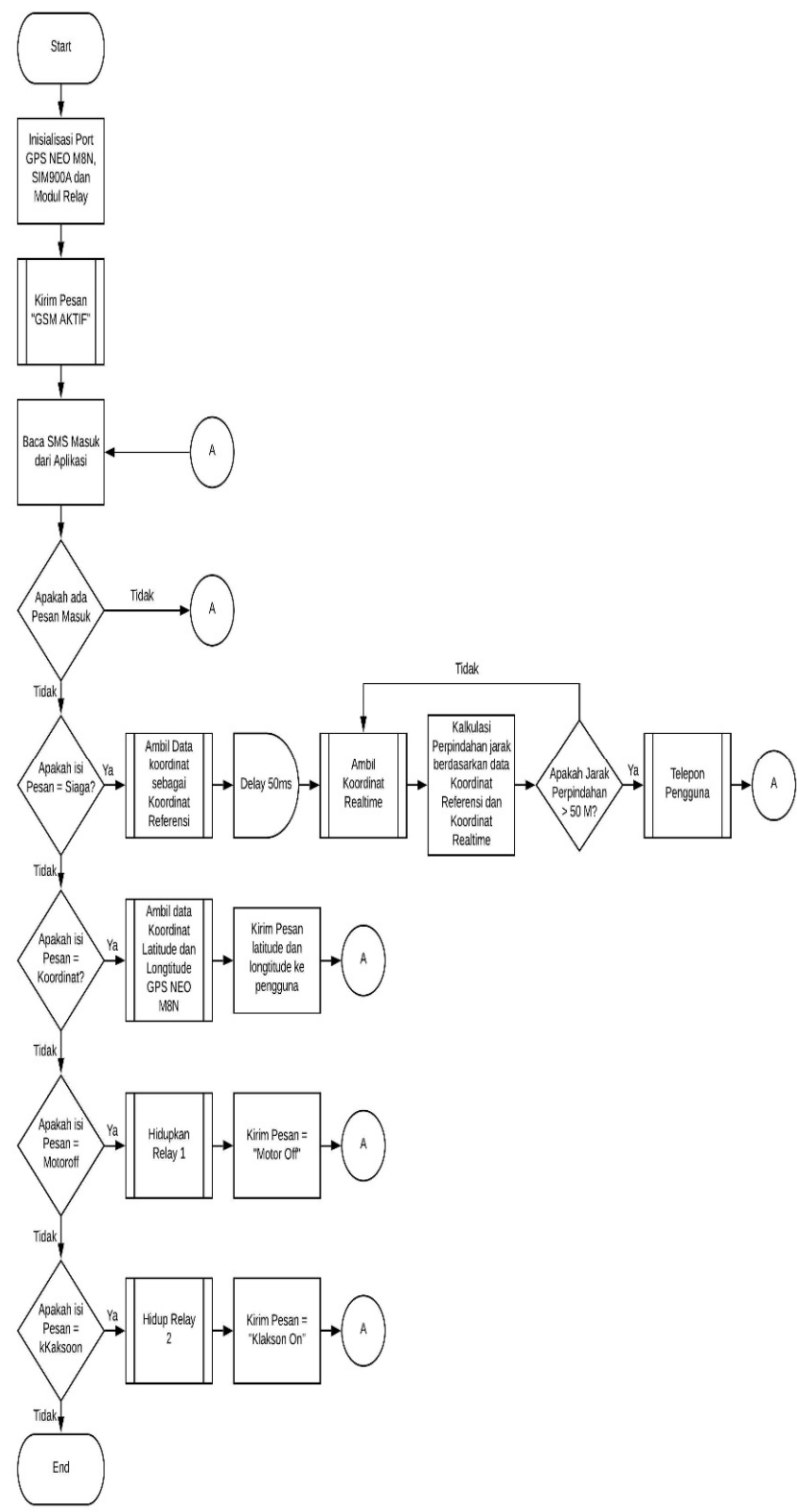

Gambar 8 : Flowchart Hardware 
2). Aplikasi Android pada Smartphone User.

Diagram alir (flowchart) pada pembuatan aplikasi Android pada Smartphone User diperlukan untuk mempermudah dalam perancangan dan pembuatan aplikasi Android untuk Sistem Keamanan Sepeda Motor dengan GPS Tracker berbasis Mikrokontroler. Diagram alir (flowchart) dari Aplikasi Android Sistem Keamanan Sepeda Motor ditunjukkan pada Gambar 3.4.

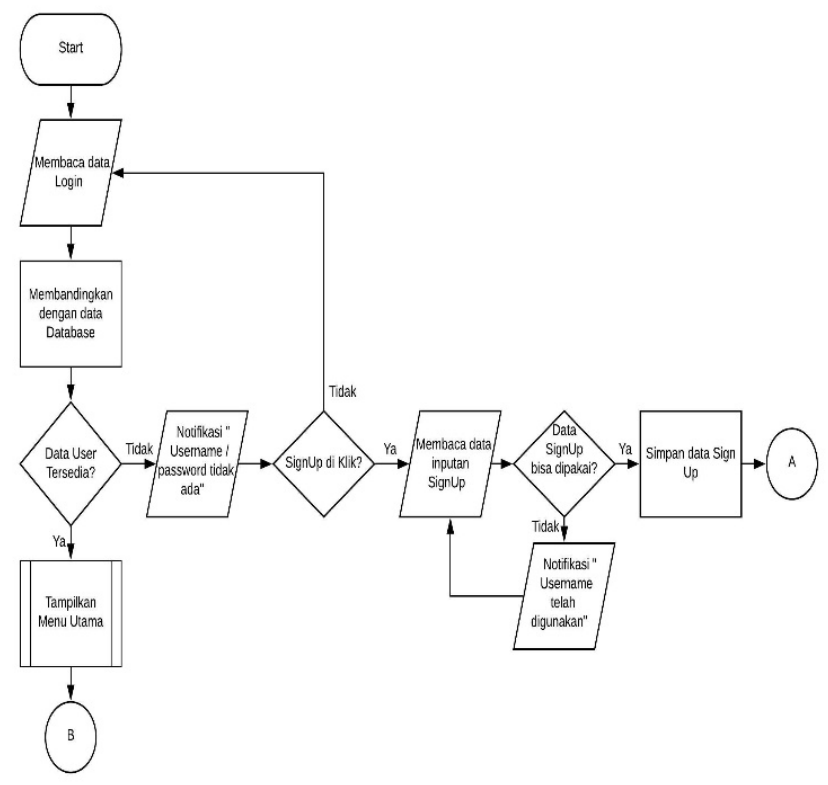

Gambar 9: Flowchart software bagian Login

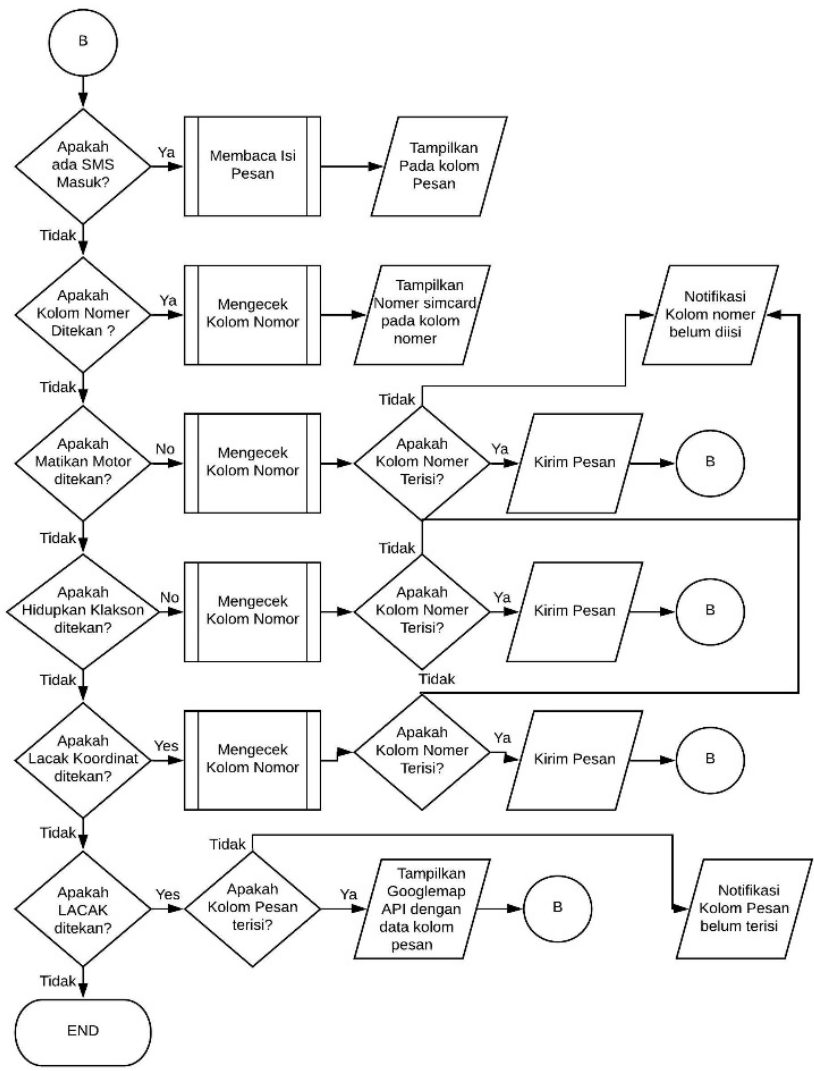

Gambar 10: Flowchart software bagian menu utama

\section{E. Keseluruhan Sistem Keamanan Sepeda Motor}

Pada penggabungan perancangan seluruh sistem bertujuan untuk memperlihatkan keseluruhan rangkaian hardware yang dipakai pada sistem keamanan sepeda motor untuk mempermudah dalam pembuatan dan peletakan komponen pada PCB saat proses perancangan layout rangkaian. Gambar 10 merupakan rangkaian dari seluruh sistem yang digunakan pada sistem keamanan sepeda motor.

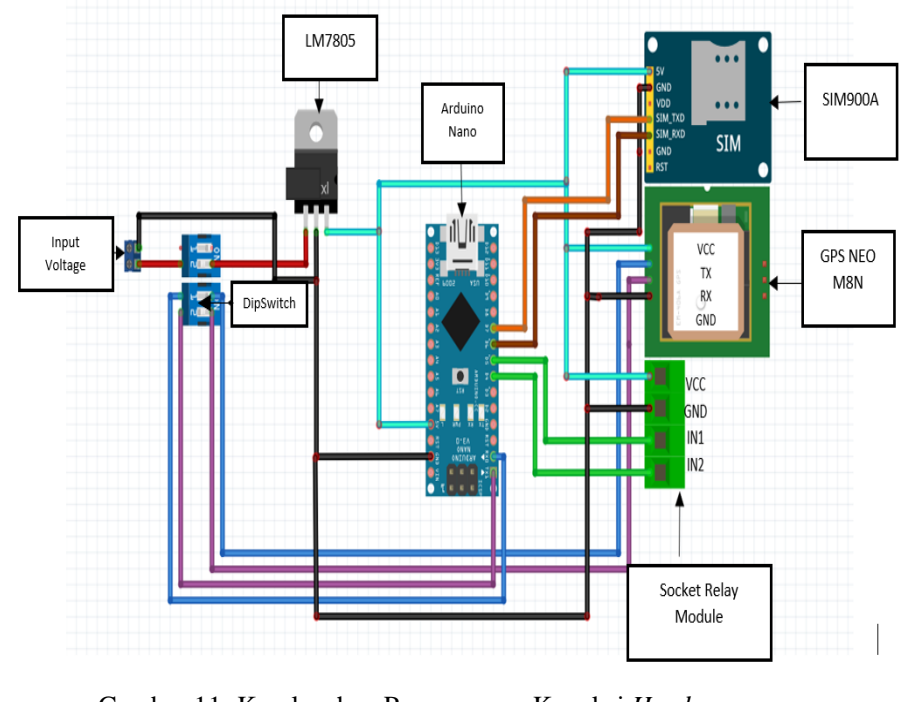

IV. HASIL DAN PEMBAHASAN

A. Realisasi Hasil Perancangan Sistem Keamanan Sepeda Motor

Alat Keamanan Sepeda Motor dengan GPS Tracker berbasis Mikrokontroler yang dirancang pada penelitian ini menggunakan GSM SIM900A sebagai sistem komunikasi antara alat dengan Smartphone pengguna. GPS NEO M8N digunakan sebagai pengambil data koordinat latitude dan longtitude bumi untuk melacak posisi sepeda motor. Relay berfungsi sebagai switching elektronik yang bekerja berdasarkan medan magnet [14]. Relay Module digunakan sebagai saklar elektronik untuk mematikan sepeda motor atau menghidupkan klakson sepeda motor [15]. Arduino Nano digunakan sebagai pengolahan data dari SIM900A, GPS NEO M8N dan Relay module. Realisasi alat keamanan sepeda motor ditunjukkan pada gambar 11 .

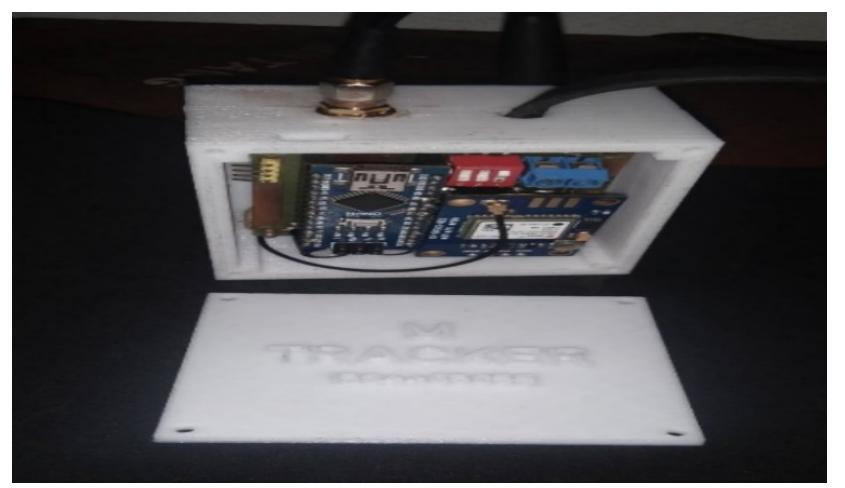

Gambar 12: Realisasi Alat Keamanan Sepeda Motor 
Chasis alat keamanan sepeda motor terdapat beberapa lubang yang sesuai dengan posisi port dari shield elektronika yang membutuhkan akses keluar chasis seperti kabel power supply, antena SIM900A, antena GPS NEO M8N, dan port USB 2.0 Micro-B pada Arduino. Spesifikasi dari realisasi alat keamanan sepeda motor ditunjukkan pada tabel 1 .

TABEL I

SPESIFIKASI KEAMANAN SEPEDA MOTOR

\begin{tabular}{|c|c|c|}
\hline No & Spesifikasi & Keterangan \\
\hline 1 & $\begin{array}{c}\text { Tinggi Alat Keamanan Sepeda } \\
\text { Motor }\end{array}$ & $4,43 \mathrm{~cm}$ \\
\hline 2 & $\begin{array}{c}\text { Panjang Alat Keamanan } \\
\text { Sepeda Motor }\end{array}$ & $6,57 \mathrm{~cm}$ \\
\hline 3 & $\begin{array}{c}\text { Lebar Alat Keamanan Sepeda } \\
\text { Motor }\end{array}$ & $6,52 \mathrm{~cm}$ \\
\hline 4 & Berat Keseluruhan & $180 \mathrm{~g}$ \\
\hline 5 & Tegangan Input & 3 Ampere \\
\hline 6 & Arus Maksimal & Arduino Nano ATMEGA \\
\hline 7 & Mikrokontroler & SIM900A \\
\hline 8 & Sistem Komunikasi & GPS NEO M8N \\
\hline 9 & Sistem Navigasi & \\
\hline
\end{tabular}

\section{B. Realisasi Aplikasi Android}

Aplikasi yang dirancang pada penelitian ini dibuat untuk operating System berbasis Android menggunakan software Thunkable. Aplikasi yang dirancang dapat dijalankan pada Android dari versi 4.4 (Kitkat) hingga versi 8.1 (Oreo). Aplikasi yang dirancang pada sistem keamanan sepeda motor berbasis SMS Gateway, dimana pesan SMS yang dikirim dari alat akan diproses oleh aplikasi yang telah dirancang. Aplikasi ini menggunakan internet untuk terhubung dengan database. Realisasi aplikasi android ditunjukkan pada gambar 12.
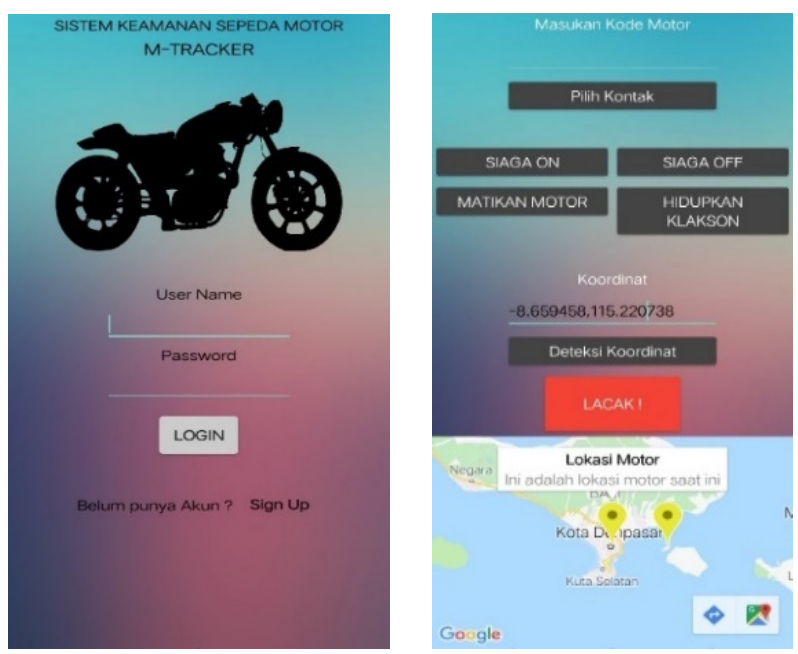

Gambar 13 : Tampilan Halaman Login. Dan Halaman pengontrolan

Aplikasi android berfungsi sebagai monitoring dan pengontrolan dari sistem keamanan sepeda motor dimana pengguna harus memiliki akun dan memasukan nomor Simcard yang telah dipasang pada alat keamanan sepeda motor. Spesifikasi aplikasi Android ditunjukkan pada tabel 2.
TABEL III

SPESIFIKASI APLIKASI ANDROID

\begin{tabular}{|c|c|c|}
\hline NO & Spesifikasi & Keterangan \\
\hline 1 & Ukuran Aplikasi & 20,36 MB \\
\hline 2 & Mode & $\begin{array}{l}\text { Online (Untuk } \\
\text { keperluan Log in) }\end{array}$ \\
\hline 3 & Jenis Aplikasi & SMS Gateway \\
\hline 4 & $\begin{array}{c}\text { Versi Android yang } \\
\text { Sesuai }\end{array}$ & 4.4 atau diatasnya \\
\hline
\end{tabular}

C. Pengujian dan Pembahasan Keseluruhan Sistem Keamanan Sepeda Motor

Pengujian dan pembahasan keseluruhan sistem keamanan sepeda motor dengan GPS Tracker berbasis mikrokontroler dan aplikasi android dilakukan dengan tujuan mengetahui apakah kedua sistem dapat bekerja sesuai rancangan yang telah dibuat. Pengujian Keseluruhan sistem keamanan sepeda motor adalah sebagai berikut:

\section{1). Pengujian dan Pembahasan Sistem Kontrol}

Pada saat mode SIAGA ON ditekan, aplikasi akan mengirim pesan kepada alat yang terpasang pada sepeda motor untuk mengambil data koordinat referensi dan mengaktifkan mode siaga dimana bila jarak motor berpindah lebih dari 50 meter dari titik referensi maka alat akan melakukan panggilan telepon ke smartphone pengguna. Ketika SIAGA OFF ditekan, alat yang terpasang pada sepeda motoer tidak akan merespon atau bertindak saat motor bergerak lebih dari 50 meter. Pengujian mode siaga ditunjukkan pada gambar 13.

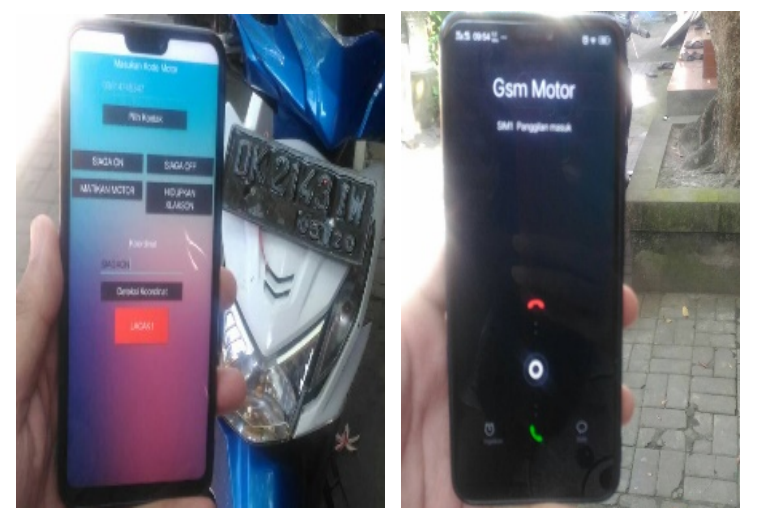

Gambar 14 : Tampilan Aplikasi ketika Mode SIAGA ON diaktifkan dan Smartphone Saat motor lebih dari 50 meter dari titik referensi

Pengujian dan pembahasan mematikan sepeda motor atau menghidupkan klakson sepeda motor dilakukan dengan tujuan untuk mengetahui apakah pengguna dapat mengontrol alat untuk mematikan sepeda motor atau menghidupkan klakson sepeda motor melalui aplikasi android.Pengujian Mematikan Sepeda Motor atau Menghidupkan Klakson sepeda motor ditunjukkan pada gambar 14. 


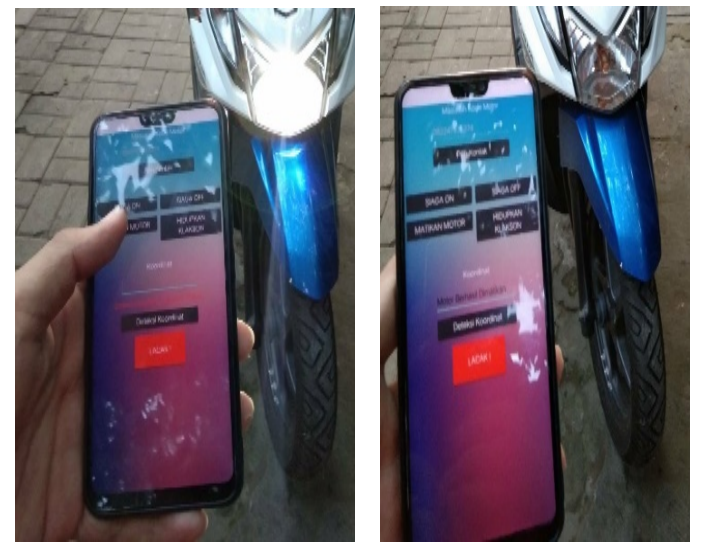

Gambar 15 : Sebelum menekan tombol Matikan motor da nSetelah menekan tombol Matikan motor

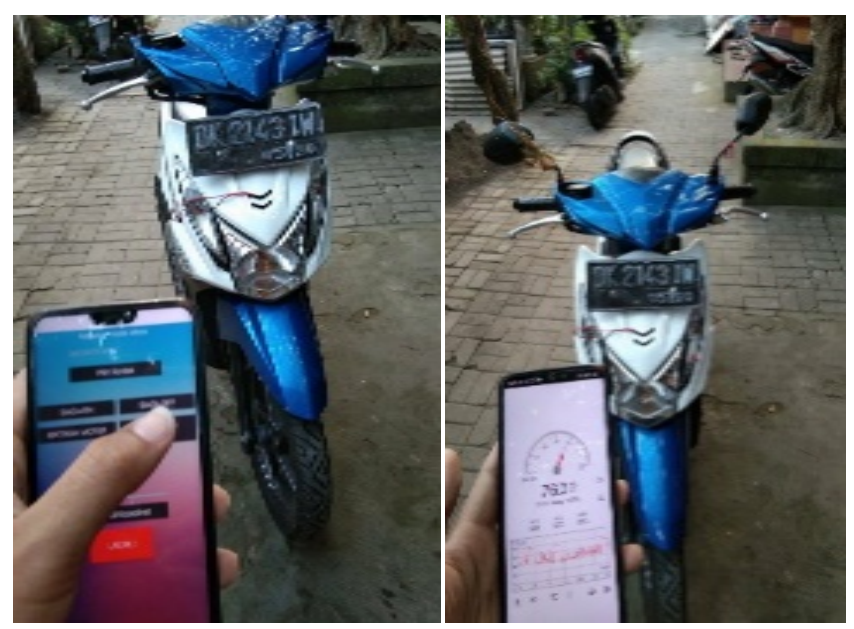

Gambar 16: Sebelum menekan tombol KLAKSON ON dan Setelah menekan tombol KLAKSON ON ditunjukkan klakson berbunyi pada aplikasi dB Meter.

\section{Pengujian dan Pembahasan Deteksi Perpindahan Jarak Sepeda Motor}

Pengujian dan pembahasan fitur deteksi koordinat dan fitur lacak dengan tampilan MAP dilakukan dengan tujuan untuk mengetahui apakah program dapat mengirimkan perintah untuk menditeksi koordinat ke alat keamanan

sepeda motor, menerima data koordinat sepeda motor berupa latitude dan longtitude, kemudian mengolah data tersebut untuk ditampilkan dalam bentuk peta atau map. Tampilan Map pada aplikasi ditunjukan pada gambar 16.
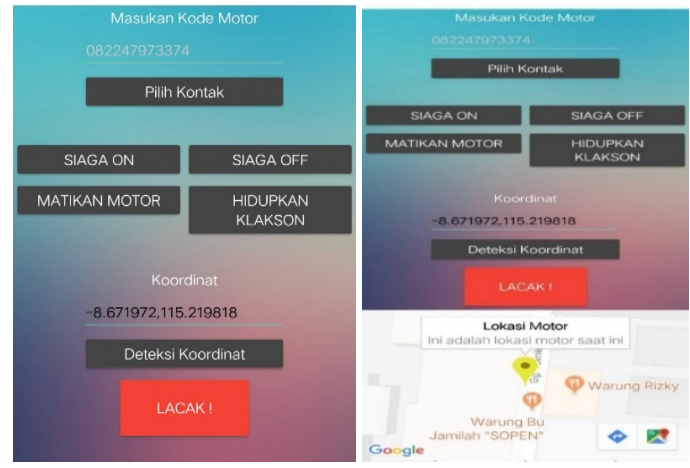

Gambar 17 : Koordinat berupa latitude dan longtitude yang diterima dari alat keamanan sepeda motor dan Tampilan peta atau map sesuai koordinat yang diterima aplikasi.
Pengujian dan pembahasan akurasi perpindahan jarak pada sistem keamanan sepeda motor dengan perpindahan jarak sebenarnya dilakukan dengan tujuan untuk mengetahui tingkat akurasi dari nilai perpindahan jarak yang dihasilkan pada sistem keamanan sepeda motor dengan jarak perpindahan sebenarnya. Pengujian dilakukan dengan memuat nilai koordinat referensi dan mengamati nilai hasil pemrosesan pembacaan jarak perpindahan pada alat keamanan sepeda motor dengan membandingkan jarak perpindahan alat sebenarnya. Pengujian dilakukan pada dua kondisi ruangan yaitu indoor dan outdoor. Hasil pengujian akurasi nilai jarak perpindahan pada sistem keamanan sepeda motor dengan jarak perpindahan sebenarnya ditunjukkan pada gambar.

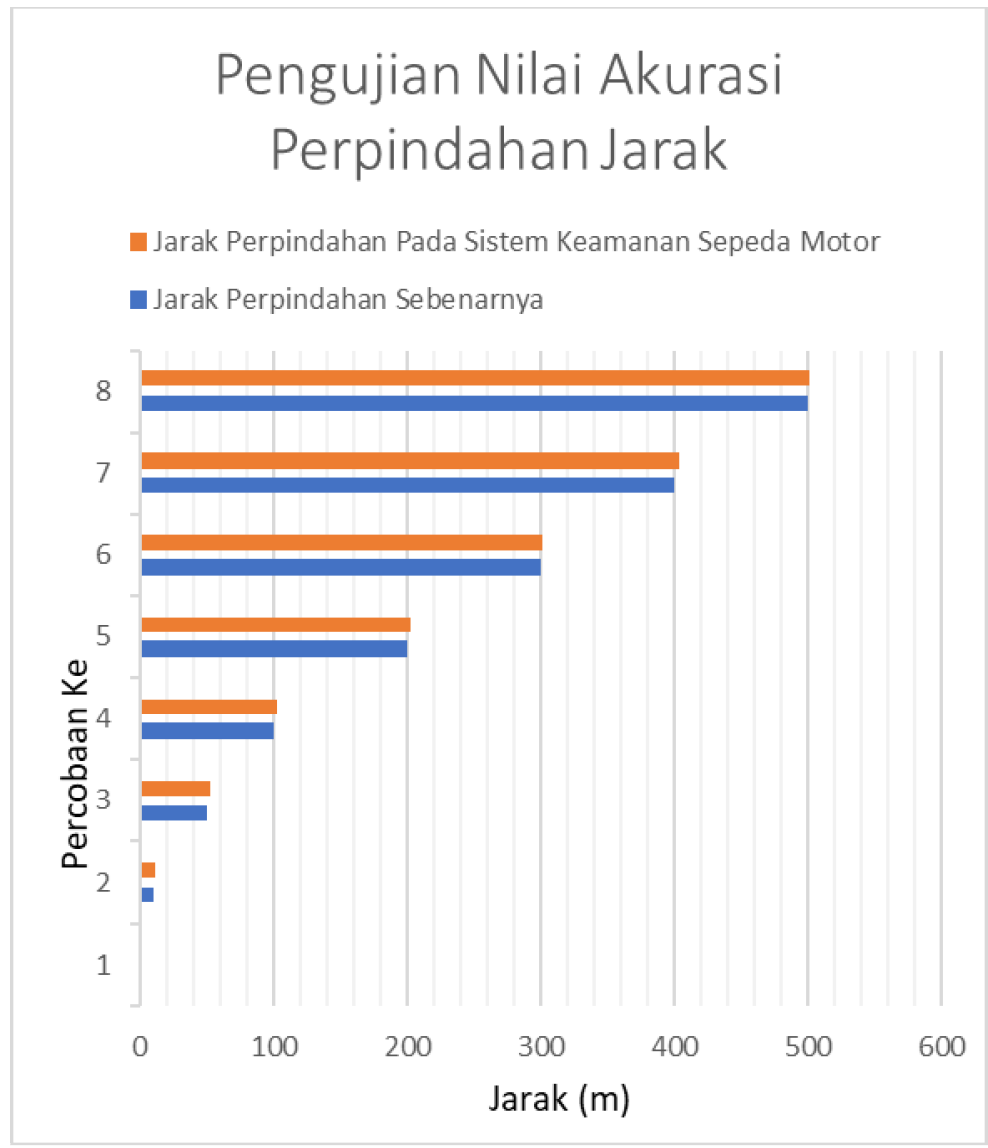

Gambar 18: Grafik Akurasi Perpindahan Jarak Sepeda Motor

Berdasarkan hasil pengujian yang ditunjukkan pada gambar diketahui bahwa nilai jarak perpindahan antara nilai yang dibaca oleh sistem keamanan sepeda motor dengan nilai jarak perpindahan sebenarnya terdapat perbedaan. Pada pengujian tersebut dapat disimpulkan bahwa toleransi keakuratan dari sistem keamanan sepeda motor yang dirancang mencapai 4 meter dari koordinat sebenarnya.

\section{KeSIMPULAN}

Simpulan dari penelitian ini adalah sebagai berikut:

Sistem Keamanan Sepeda Motor yang dirancang menggunakan Arduino Nano, SIM900A, GPS NEO M8N, dan Relay Module dapat berkomunikasi dengan smartphone 
Majalah Ilmiah Teknologi Elektro, Vol. 18, No. 3, September-Desember 2019

DOI: https://doi.org/10.24843/MITE.2019.v18i03.P09

melalui SMS sudah dapat mematikan sepeda motor atau menghidupkan klakson. Pemilik Sepeda Motor dapat mengetahui koordinat dari sepeda motor ketika berpindah lebih dari 50 meter dari titik awal melalui aplikasi smartphone. Toleransi dari keakuratan pembacaan perpindahan jarak pada alat keamanan sepeda motor yang dirancang dengan jarak perpindahan sepeda motor sebenarnya kurang lebih 2 meter. Aplikasi Android yang dibangun sudah dapat berkomunikasi antara sistem keamanan sepeda motor dengan GPS Tracker Berbasis Mikrokontroler dengan 3 operator selular berbeda dengan waktu pairing berbeda. Operator telkomsel mempunyai waktu pairing tercepat yaitu 6 detik, diikuti M3 dengan waktu pairing 31 detik, dan XL dengan waktu pairing paling lama yaitu 310 detik.

\section{REFERENSI}

[1] (2010). Grafik Proyeksi Penduduk Indonesia berdasarkan Hasil Sensus Penduduk 2010.[Online]. Available at : https://www.bps.go.id/

[2] (2016). Meresahkan, Nyaris Tiap Hari Ada Motor yang Hilang di Bali, Ini Datanya.[Online]. Available at: https://bali.tribunnews.com/2016/12/29/meresahkan-nyaris-tiap-hariada-motor-yang-hilang-di-bali-ini-datanya

[3] (2010). Sejarah Asul Usul Sepeda Motor.[Online]. Available at: http://www.cosmobikers.com/online/cb-news/634-sejarah-asulusulsepeda-motor.html

[4] (2017). Apa itu Arduino?. [Online]. Available at: http://www.immersalab.com/apa-itu-arduino.htm

[5] A. M. Putra, C. G. I. Partha, I. N. Budiastra, 2016. Rancang Bangun Penyeimbang Arus Beban Pada Sistem 3 Fasa Menggunakan Mikrokontroller Atmega 2560. Universitas Udayana, 16(1), pp. 21-31.

[6] (2012). Global Positioning System (GPS). [Online]. Available at: https://defiaryanto.wordpress.com/2012/02/17/global-positioning-syste m-gps/

[7] I. M. Nova Suardiana, I. G. A. P. Raka Agung, Lie Jasa.,2016. RancangBangun SistemPembacaan Jumlah Konsumsi Air Pelanggan PDAM Berbasis Mikrokontroler ATMEGA328. Universitas Udayana, 16(1), pp. 31-40.

[8] (2016). SIM900 Connect to Arduino [Online]. Available at http://www.belajarduino.com/2016/06/sim900a-connect-to-arduinogetting.html

[9] I. P. Warma Putra, M. Sudarma, N. Pramaita., 2016. Rancang Bangun Sistem Enkripsi Dan Dekripsi SMS Menggunakan AES dan Blowfish Cipher serta Kombinasinya Pada Telepon Seluler Berbasis Android. Universitas Udayana, 18(1), pp. 1-8.

[10] (2019). Tools Untuk Membuat Aplikasi Android Selain Android Studio. [Online]. Available at https://www.codepolitan.com/tools-untukmembuat-aplikasi-android-selain-android-studio-59b76a6f7521e

[11] K. R. Adi Prasetya, W. Setiawan, I. G. A. K. Diafari Djun., 2016. Visualisasi Kecepatan Kendaraan Menggunakan Instant Messaging Berbasis Android. Universitas Udayana, 12(2), pp. 1-6.

[12] Gusmanto, d., Elang, D.M., Bomo, W.S., 2016. Rancang Bangun Sistem Peringatan Dini Dan Pelacakan Pada Kendaraan Sepeda Motor Dengan Menggunakan Mikrokontroler Arduino Nano. Universitas Tanjungpura, 2(1), pp. 1-11.

[13] (2014). Teori Pengukur Jarak. [Online]. Available at https://blogs.itb.ac.id/anugraha/2014/09/10/teori-pengukuran-jarak/

[14] M. Yogi Hendrayanto, I. B. Alit Swamardika, P. Arya Mertasana., 2016. Rancang Bangun Sistem Smart ChargingMenggunakan Panel Surya pada Robot 6WD Berbasis Mikrokontroler Atmega 2560. Universitas Udayana, 17(1), pp. 42-51.

[15] (2015). Pengertian Relay dan Fungsinya. [Online]. Available at https://teknikelektronika.com/pengertian-relay-fungsi-relay/ 


\section{\{ Halaman ini sengaja di kosongkan\}}

